IZA DP No. 8770

Private Tutoring: Evidence from India

Mehtabul Azam

January 2015 


\title{
Private Tutoring: Evidence from India
}

\author{
Mehtabul Azam \\ Oklahoma State University \\ and IZA
}

\section{Discussion Paper No. 8770 \\ January 2015}

\author{
IZA \\ P.O. Box 7240 \\ 53072 Bonn \\ Germany \\ Phone: +49-228-3894-0 \\ Fax: +49-228-3894-180 \\ E-mail: iza@iza.org
}

\begin{abstract}
Any opinions expressed here are those of the author(s) and not those of IZA. Research published in this series may include views on policy, but the institute itself takes no institutional policy positions. The IZA research network is committed to the IZA Guiding Principles of Research Integrity.

The Institute for the Study of Labor (IZA) in Bonn is a local and virtual international research center and a place of communication between science, politics and business. IZA is an independent nonprofit organization supported by Deutsche Post Foundation. The center is associated with the University of Bonn and offers a stimulating research environment through its international network, workshops and conferences, data service, project support, research visits and doctoral program. IZA engages in (i) original and internationally competitive research in all fields of labor economics, (ii) development of policy concepts, and (iii) dissemination of research results and concepts to the interested public.
\end{abstract}

IZA Discussion Papers often represent preliminary work and are circulated to encourage discussion. Citation of such a paper should account for its provisional character. A revised version may be available directly from the author. 


\section{ABSTRACT}

\section{Private Tutoring: Evidence from India}

Drawing on the nationally representative "Participation and Expenditure in Education" surveys, we document the incidence and cost of private tutoring at different stages of schooling over the last two decades in India. As private tutoring involve two decisions: a) whether to take private tuition or not, and b) how much to spend on private tutoring conditional on positive decision in (a), we analyze the determinants of the two decisions separately using a Hurdle model. We find that private tutoring is not a new phenomenon in India: a significant proportion of students at each stage of schooling took private tutoring even in 1986-87, and there has been no dramatic increase in those proportions. Students in urban areas and private schools are not only more likely to take private tutoring but also spend more on private tutoring. We also find that demand for private tutoring is inelastic at each stage of schooling, which implies that the private tutoring is a necessary good in the household consumption basket. We also find evidence of pro-male bias in both decisions regarding private tutoring.

JEL Classification: $\quad$ I21, I22, I24

Keywords: private tutoring, coaching, costs, India, Hurdle model

Corresponding author:

Mehtabul Azam

326 Business Building

Spears School of Business

Oklahoma State University

Stillwater, OK 74078

USA

E-mail: mazam@okstate.edu 


\section{Introduction}

It is evident to most of the casual observers in urban centers in India that a large proportion of students at secondary and senior-secondary levels attend private tuitions.11 This is perhaps driven by the fact that the performances in public examinations at the end of secondary school (grade 10) and senior secondary school (grade 12) are important determinants of success, given the intense competition for entering into desired academic streams at the higher levels.2.$^{2}$ However, there exists limited documentation on the prevalence of private tutoring in India to support what is evident to the most casual observers at the urban centers. Studies on private tutoring in India are few and based on sporadic surveys. Based on a random sample of 4,031 students studying in Grade IX-X in 2005-2006 in 49 schools from Thiruvananthapuram, Pune, Nalgonda and Varanasi districts in four states: Kerala, Maharashtra, Andhra Pradesh, and Uttar Pradesh, respectively, Sujata (2014) reports that $44.7 \%$ were seeking private tutoring for one or more subjects at secondary level (Grade IX-X). The extent of private tuition varies among four sampled states, ranging from 55\% to 32.26\%. Aslam and Atherthon (2012) use SchoolTells survey, a survey of primary schools in two north Indian states: Uttar Pradesh and Bihar. The SchoolTells survey was carried out in the 2007-08 school year in 160 rural primary schools across 10

\footnotetext{
${ }^{1}$ Private tutoring is defined here as fee-based tutoring that provides supplementary instruction to children in academic subjects they study in the mainstream education system (Dang and Rogers, 2008). Private tutoring is widely called shadow education because in many locations it coexists with mainstream schooling and mimics the regular school system-as the school system grows, so does the shadow; and as the curriculum in the school changes, so does the curriculum in the shadow (Bray and Lykins, 2011).

${ }^{2}$ Although there exists a pervasive belief that private tutoring provides a distinctive edge in exams, the evidence on impact of paid tutoring on achievement in India is very limited. Based on achievement tests in mathematics and reading ability for over 4000 students in grade 2 and 4 from rural schools of two Indian states, Atherton and Aslam (2012) finds positive affect of private tutoring on private and government school students. Dongre and Tewary (2014) using ASER data from rural India find positive and significant impact of private tutoring on learning levels of students at elementary levels (grade I-VIII). Evidence at the secondary and senior secondary levels are mostly anecdotal. Moreover, the evidence from other countries are conflicting. Dang (2007) and Dang and Rogers (2008) investigate the effect of private tutoring in Vietnam; Ono (2007) explores private tutoring in Japan. These studies usually indicate a strong positive effect of private tutoring on students' performance. In contrast, Briggs (2001), Gurun and Millimet (2008) and Kang (2007) examine the impact of private tutoring in the US, Turkey and South Korea, find negligible effects of tutoring on pupils' educational outcomes.
} 
districts of the sample states. Nearly a fifth of all children surveyed were taking private tuition.

The phenomenon of private tutoring is not restricted to higher grades, and urban areas. ASER (2013), a household-based survey covering rural India, reports that in 2013, 22.6 percent of children in grade I-V (primary school) in rural India attend private tutoring, while 26.1 percent of children in grade VI-VIII (middle school) in rural India attend private tutoring. ASER survey only collect information on children in age 3-16 residing in rural areas, thus excluding majority of children attending secondary and senior secondary levels. In addition ASER is restricted to rural areas, and thus have no information about urban areas 3

From a policy perspective, it is important to not only have reliable estimates of prevalence of private tutoring but also the socio-economic profiles of those attending private tutoring. From an education production perspective another important question remains whether private tutoring adds to students' achievement. As pointed out in footnote 2, the evidence regarding this is very limited in India, and the limited evidence from other countries are conflicting. Nevertheless, the socio-economic profile of students attending private tutoring provide indicative evidence about whether private tutoring is used as remedial measure (additional help is provided to lagging students to catch up with the rest) or used as a tool to maintain or exacerbate already existing differentials resulting from differences in parents educational/economic backgrounds. If better educated parents and richer families are clearly able to pay for private tutoring, this has important implications for equality of opportunities. Moreover, it goes against the spirit of the Right to Education Act that provides for the: Right of children to free and compulsory education

\footnotetext{
${ }^{3}$ ASER has been conducted every year since 2005 in all rural districts of India. ASER started asking tuition status of children in 2007 only. ASER 2013, for the first time, recorded how much rural households spend per month on private tuition. However, ASER does not collect information on total private spending by household on child's education. In addition, it also lacks socio-economic information of the households.
} 
till completion of elementary education in a neighborhood school. $4^{4}$ Section $3(2)$ of the Act says no child shall be liable to pay any kind of fee or charges or expenses which may prevent him or her from pursuing and completing the elementary education. Private tutoring can also create inefficiencies in education system itself. Particularly problematic are situations in which teachers deliberately reduce the effort that they devote to their regular classes in order to preserve energy for private tutoring (Bray and Lykins, 2011) ${ }^{5}$ For example, Jayachandran (2013) study in Nepal finds that teachers who offer tuition, cover less material during the school day in order to generate demand for their tutoring. She also finds that offering tuition make government school teachers 7.1 percentage points less likely to teach for the whole period compared to their counterparts in private schools.

In this paper, we first document the prevalence and cost of private tutoring at different stages of schooling over the last two decades using the nationally representative "Participation and Expenditure in Education surveys" conducted by National Sample Survey, Government of India. These surveys are not only nationally representative (covers both urban and rural areas) but also household-based rather than school-based. This enables all children to be included - those who have never been to school or have dropped out, as well as those who are in government schools or private schools. Second, since private tutoring involves two part decision making on the part of the parents: (a) the decision to enroll the child for the supplementary private tutoring, and (b) having enrolled the child for private tutoring, how much to spend on private tutoring, we use the Hurdle model to separately analyze the determinants/drivers of those decisions.

The findings of the paper are the following. First, private tutoring has been prevalent in India for some time at each stage of schooling $!^{6}$ In 2007-08, about 31 percent of

\footnotetext{
${ }^{4}$ The Right to Education Act (RTE) was approved by the Parliament of India in 2009, and came into effect from 1 April 2010.

${ }^{5}$ Interestingly, Section 28 of the Right to Education Act banned teachers in schools from teaching students through private tutorials, however it is not clear how this is implemented on ground.

${ }^{6}$ India is not an outlier, substantial private tutoring industries can be found in countries as economically and geographically diverse as Cambodia, the Arab Republic of Egypt, Japan, Kenya, Morocco, Romania, Singapore, the United States, and the United Kingdom (Dang and Rogers, 2008). Dang and Rogers (2008)
} 
the students at secondary and senior secondary levels took private tutoring, while about 20 and 13 percent of students at the primary and middle level took private tutoring, respectively. Moreover, the students who took private tutoring, the cost of tutoring constitute about 43 percent of the entire private expenditure on education, and about 16.5 percent of household per capita expenditure. Second, controlling for other factors, the prevalence of private tutoring increases with the stages of schooling and being enrolled in private or English-medium school. Moreover, these are also associated with higher expenditure on private tutoring. Students in urban areas or living in households with better educated household heads, higher household per capita consumption expenditures are not only more likely to take private tutoring but also spend more on private tutoring. Third, the demand for private tutoring is inelastic (elasticity is positive but far less than one) which implies private tutoring is a necessary good in the household consumption basket. Moreover, the demand is inelastic at all stages of schooling. Fourth, there exists pro-male bias in both decisions regarding private tutoring: boys are not only more likely to attend private tutoring but also spend more conditional on taking private tutoring.

The rest of the paper is organized as follows. Section 2 details the data, Section 3 describes the methodology followed in this paper, Section 4 presents and results, and Section 5 concludes.

\section{Data}

This paper uses three rounds of all-India survey on 'Participation and Expenditure in Education', conducted during July 1986- June 1987 (42nd Round), July 1995-June 1996 (52nd Round), and July 2007 - June 2008 (64th Round) by the National Sample Survey Organization (NSSO). The NSSO 'Participation and Expenditure in Education' surveys

survey evidence on the prevalence of tutoring in 23 developing and developed countries, and report that in almost all of them, 25-90 percent of students at certain levels of education are receiving or recently received private tutoring. 
collect information on (a) participation of persons aged 5-24/29 years in the education system of the country (b) private expenditure incurred by household on education of child and (c) the extent of educational wastage in terms of dropout and discontinuance, and its causes. The three rounds are spaced roughly by a decade and provide a picture how participation and expenditure in education has evolved in the last three decades.

The 2007-08 survey surveyed of a sample of 445960 persons, from 63318 rural households and 37263 urban households spread over the country. The 1995-96 survey surveyed 371608 persons, from 43076 rural households and 29807 urban household, while the 1986-87 survey surveyed 430662 persons, from 49651 rural households and 27360 urban households. All the three surveys are nationally representative surveys.

All three rounds of NSS surveys collect information about household, such as total consumer expenditure, demographic profile of each individual in households. In addition, they further collect information on current attendance for every household member in age 5-24/29 age group. $7^{7}$ For each currently attending child, the surveys collect information on type of education, level of current attendance, class/grade/year of study, type of management of educational institution, details of benefits received, if any, such as fee waiver, scholarship, free study materials and free mid-day meals, and detailed break-up of private educational expenditure. Private expenditure on education is the sum total of all the expenditures incurred by the student on education (towards school fees, books and stationery, uniform, transport, private tutoring/coaching, study tours, etc.). This include all the expenditures incurred and/or to be incurred during the current academic year on the education of the household members, aged 5-29 years who are currently attending. Those currently not attending any educational institution in age 5-29/24 were asked

\footnotetext{
${ }^{7}$ While the 2007-08 survey collected detailed information on education for persons in the age group 5-29 years, the 1995-96 survey collected that information only for age group 5-24 years, and the 1986-87 survey collected similar information for persons enrolled in primary and higher levels. Although, there is some variation in age group of persons for whom education expenditure is collected across different surveys, the relevant age group for primary (6-10), middle (11-13), secondary, senior secondary (14-17), and tertiary (18-20/22) is covered in all three rounds. Since delayed enrollment still an issue in India, we restrict our sample to all children in age 6-24 age group.
} 
whether they had ever been enrolled, and if so whether they had completed their education or discontinued midcourse, and what was the main reason for dropping out or for non-enrollment. The data classifies institution in four categories: government, local body, private aided and private unaided 8 We reclassify local body institutions as government institutions.

Table 1 reports the number of individuals in age group 6-24, and number of those who are currently attending. Education expenditure are missing for few currently attending children. Our main analysis is based on the children in age 6-24 who are currently attending and for whom private education expenditure is reported. Thus in our sample we have about 93546, 89979, and 91294 currently attending students in 1986-87, 1995-96, and 2007-08, respectively.

\section{Methodology}

The currently attending students who did not receive any private tutoring spent zero on it. In this case, the Ordinary Least Squares (OLS) method for the whole sample is not appropriate. The private tutoring involve two part decision making: a) whether to take private tuition or not; b) if yes in part (a), how much to spend on the private tutoring?

We use a Hurdle model (Wooldridge, 2010, p 690-96) to separate the initial decision of $w=0$ from the decision of how much $w$ given positive $w$, where $w$ is the expenditure on private tutoring 9 Hurdle Models are two-tier models because the hurdle or first tier

\footnotetext{
${ }^{8}$ The 1986-87 data classifies schools into private and public only. All schools/institutions run by central and state governments, public sector undertakings or autonomous organizations completely financed by government are treated as government institutions. All institutions run by municipal corporations, municipal committees, notified area committees, zilla parishads, panchayat samitis, cantonment boards, etc., are treated as local body institutions. A private aided institution is one which is run by an individual or a private organization and receives maintenance grant from a government or a local body. A private unaided institution is one which is managed by an individual or a private organization and is not receiving maintenance grant either from a government or from a local body. We reclassified the schools run by local bodies as government schools.

${ }^{9}$ Tobit model is another available alternative, however, it is identified only if the assumptions of normality and homoskedasticity are fulfilled (Deaton, 1997). Moreover, it assumes that a single mechanism determines the choice between $w_{i}=0$ vs $w_{i}>0$ and the amount of $w$ given $w>0$. In particular,
} 
is the decision of whether to choose a positive $w$ or not $(w=0$ versus $w>0)$, and the second tier is the decision of how much to spend conditional on spending a positive amount $(w \mid w>0)$. A simple Hurdle model can be written as follows:

$$
\begin{gathered}
P\left(w=0 \mid x_{1}\right)=1-\Phi\left(x_{1} \gamma\right) \\
\log (w) \mid x_{2}, w>0 \sim \operatorname{Normal}\left(x_{2} \beta, \sigma^{2}\right)
\end{gathered}
$$

where $w$ is the is private tutoring expenditure, $x$ is a vector of explanatory variables, $\gamma$ and $\beta$ are parameters to be estimated while $\sigma$ is the standard deviation of $w \sqrt{10}$ Equation (1) shows the probability that $w$ is positive or zero, and Equation (2) stipulates that conditional on $w>0, w \mid x_{2}$ follows a lognormal distribution. One can obtain an estimate of $\gamma$ from a probit using $w=0$ versus $w>0$ as the binary response. Because of the assumption that conditional on $w>0, \log (w)$ follows a classical linear model, the OLS estimator $\beta$ is consistent, and the consistent estimator of $\sigma$ is just the usual standard error from the OLS regression ${ }^{11}[12$

Our explanatory variables include micro level variables for individuals (age and gender), for households (location, number of siblings, caste, household consumption expendi$\overline{\partial(P(w>0 \mid x)) / \partial x_{i} \text { and } \partial E(w \mid x, w>0)} / \partial x_{i}$ are constrained to have the same sign. In addition, the standard Tobit model implies that that the relative effects of two continuous explanatory variables, say $x_{j}$ and $x_{h}$, on $P(w>0 \mid x)$ and $E(w \mid x, w>0)$ are identical i.e. $\frac{\partial(P(w>0 \mid x)) / \partial x_{j}}{\partial(P(w>0 \mid x)) / \partial x_{h}}=\frac{\beta_{j}}{\beta_{h}}=\frac{\partial E(w \mid x, w>0) / \partial x_{j}}{\partial E(w \mid x, w>0) / \partial x_{h}}$ (Wooldridge, 2010, p 690). So, if $x_{j}$ has twice the effect as $x_{h}$ on the participation decision, $x_{j}$ must have twice the effect on the amount decision, too.

${ }^{10}$ The same regressors often appear in both parts of the model, however, there is no reason for $x_{1}=x_{2}$. It is an advantage of two part model that is provides the flexibility to have different regressors in the two parts (Cameroon and Trivedi, p 539).

${ }^{11}$ Though the log transformation reduces heteroscedasticity and the distribution looks much closer to normal distribution, both homoscedasticity and normality are not necessary for consistency of the OLS estimators. The key assumption needed is $E[\log (w) \mid w>0, x]$ is linear in $x$ (Cameroon and Trivedi, p $541)$.

${ }^{12}$ The conditional private tutoring equation could suffer from sample selectivity bias as private tutoring expenditure functions are estimated only for a sub-sample (students who took private coaching), which could be non-randomly selected from the entire currently attending students. One possible solution is to correct for selectivity using the Heckman two-step approach but in the absence of convincing exclusion restrictions (especially in urban areas), we have not proceeded with this route. Maddan (2008) finds that there is comparatively little difference between the selection and two-part models and the policy conclusions to be drawn from the two approaches would be very similar. 
ture, and household head education), and for school (stages of schooling, type of school, school tuition fees and distance to school) ${ }^{13}$

\section{Results}

\subsection{Prevalence and cost of the private tutoring}

Table 2 presents the incidence of private tutoring by different classifications. The private tutoring phenomenon is not a recent one (panel (a) of Table 2): in 1986-87 also, a significant proportion of students reported taking private tutoring. It is true that the proportion of students taking private tutoring has increased in India over time, but this increase has been gradual. In 2007-08, 18.8 percent of currently attending students in age group 6-24 received private coaching, while in 1986-87, 15.3 percent of students received private coaching. Thus, there has been an increase in prevalence of private tutoring but the increase is not dramatic. Thus it could be precluded that private tutoring is only a recent phenomenon, it is in fact entrenched into Indian education system.

More students attend private tutoring in urban areas compared to rural areas: in 2007-08, 27.7 percentage of urban currently attending students in age group 6-24 took private coaching, whereas in rural areas only 15.7 percent took private coaching. The prevalence of private tutoring is much higher at secondary and senior secondary levels compared to lower levels. Incidentally, these two levels also terminate into two important high-stake exams in India: matriculation (at the end of grade 10) and intermediate (at the end of grade 12). Most of the entrance exams for engineering and medical collages are based on the course materials covered during the two years in the higher secondary level. In 2007-08, about 41.2 (25.0) percent of students attending senior secondary school in urban (rural) areas took private coaching. This is compared to 27.5 (22.0) percent in

\footnotetext{
${ }^{13}$ About 66 (79) percent of students did not pay any school fees in 2007-08 (1987-88). As we include $\log$ of school fees in our models, to avoid loss of observations, we replaced the missing values with mean and include an indicator variable of free education if school fees paid is zero.
} 
1986-87. At the secondary level, 40.4 (26.6) percent of students in urban (rural) areas took private coaching in 2007-08. This is compared to 36.3 (27.0) percent in 1986-87.

What seems more interesting is that the prevalence of private tutoring is higher in private-aided and private-unaided schools at primary and middle school levels, while prevalence is comparable at secondary and senior secondary levels (panel (b) of Table 2). The boys are marginally more likely to take private tutoring compared to girls at each stage of schooling (panel (d) of Table 2). There exists substantial differences across social groups and consumption quintiles (panel (c) and (e) of Table 2). At secondary level, only 21.6 percent of students belonging to poorest $20 \%$ of population took private tutoring in 2007-08, whereas 38.8 percent of students belonging to top $20 \%$ of the population took private coaching. Similarly, at the secondary level, only 18.0 percent of ST students attend private tutoring compared to 25.9 percent of SC students and 32.6 percent of non-SC/ST students. If private tutoring is used as something which provide an edge compared to the peers as opposed to a remedial measure, then these gaps have equity implications.

The average cost of private tutoring to those who took private tutoring is about 42.7 percent of total private education expenditure (Table 3), which is about 16.5 percent of household per capita expenditure ${ }^{14}$ For those who took private tutoring in 2007-08, the cost of tutoring constitute about 47.5 (41.7) percent of total private education expenditure at primary (middle) stage. While at the secondary and senior secondary stage private tutoring constitute about 40 percent of total private expenditure on education. Private tutoring expenses as proportion of total private education expenditure might not be a very good indicator of the burden faced by households as education is free of school tuition fee in most government schools/private-aided schools ${ }^{15}$ Nevertheless, a fixed sum of money has to be paid such as development fee, library fee, etc. In addition, students might incur some expenses on transportation, uniform, books etc.

\footnotetext{
${ }^{14}$ Total private education expenditure is sum of all the expenditures incurred by the student on education (towards school fees, books and stationery, uniform, transport, private coaching, etc.).

${ }^{15}$ As noted earlier, about 66 (79) percent of students did not pay any school fees in 2007-08 (1987-88).
} 
A better mean of benchmarking the burden that private tutoring places on households is to look at the ratio of private tutoring expenditure on a child to household per capita expenditure. On average, the cost of private tutoring is 3.1 percent of household per capita consumption expenditure, however, it is 16.5 percent of per capita consumption expenditure if we consider only those students who actually incurred expenses on private coaching. The burden seems much higher for students at the senior secondary level (about 28.5 percent in 2007-08). The burden increases with the stage of schooling.

\subsection{Determinants of private tutoring}

Table 4 presents the results of the two decisions households make regarding private tutoring: a) whether to send the child for private tutoring or not, and b) how much to spend on private tutoring conditional on a positive decision in (a)? Column (1), (2), and (3) of Table 4 reports determinants of private tutoring through a probit model in 1986-87, 1995-96, and 2007-08, respectively ${ }^{16}$

Compared to primary school, the probability of taking private tutoring is higher at the middle, secondary, and senior secondary levels, while lower at the tertiary level. For example, in 2007-08 (column (3) of Table 4), compared to a child at primary school, a child at middle school is 5 percentage points more likely to receive private tutoring. Similarly, a child enrolled at the secondary (senior secondary) level is 13.7 (12.5) percentage points more likely to take private tutoring. What is noticeable is the increase in probability of taking private tutoring at the senior secondary level over time: a child at the senior secondary level was 7.1 percentage points more likely to take private tutoring in 1986-87 compared with a child enrolled at primary stage, while in 2007-08, a child at secondary level is 12.5 percentage points more likely to take private tutoring in 2007-08. A rural student is about 10 percentage points less likely to attend private coaching in 2007-08.

\footnotetext{
${ }^{16}$ Given that majority of our interest variables in the participation decision are indicator variables, and we control for district fixed effects, we estimated the linear probably model for ease of computation and interpretation.
} 
This rural disadvantage was existing in earlier periods also.

There seems a statistically significant gender bias in the household decision to send a girl child for private coaching. A girl child in 2007-08 is 2 percentage points less likely to attend private coaching. Gender bias in the decision to enroll a child in school is also documented in Kingdon (2005). Estimating the model separately for each stage of schooling, the pro-male gender bias in decision to take private coaching is observed at each stage of schooling except at the tertiary level (appendix Table A1). In 2007-08, a girl child is 4 (3.3) percentage points less likely to take private tutoring at the secondary (senior secondary level), whereas a girl child is only $2.2(1.0)$ percentage points less likely to receive private tutoring at middle or primary level. Hence, the gender bias seems to increase with the levels of schooling.

In 2007-08, a child at private-unaided (private aided) school is 1.6 (4.0) percentage points more likely to attend private tutoring compared to a child at government school. It is interesting to note that students at private-aided schools are more likely to attend private tutoring than students at private-unaided schools. The financing for privateunaided schools are through school fees whereas private-aided schools get money from government. Moreover, the students at private schools were more likely to attend private tutoring even in the earlier periods. Given that private schools are considered more effective in imparting education, the private tutoring as remedial measure for poor quality finds less support. Similarly, a child at English medium school is more likely to attend private coaching. This is contrary to the view that the students in private schools receive less tutoring than their counterparts in public schools, on the grounds that the private schools are already more closely attuned to their clients and are already charging fees to permit them to meet those clients' needs. One explanation for private school students more likely to attend private tutoring is that parents already have disposable income for private schooling, and have already demonstrated their willingness to use the market to secure an educational edge for their children (Bray and Lykins, 2011). The higher 
probability of private tutoring for private-aided school students can perhaps be explained by the fact that households use some of money they save, by paying less school fees compared to private schools, on providing supplementary education.

Compared to non-SC/ST students, ST (SC) students are 5.5 (2.2) percentage points less likely to attend private coaching in 2007-08. The disadvantage of ST students have increased over time. Moreover, ST students are less likely to attend private tutoring at each stage of schooling (appendix Table A1). In contrast, the disadvantage of SC students is not statistically significant at senior secondary and tertiary levels. The increase in disadvantage of ST students can perhaps be explained by the geographical isolation of STs. Household head's education also has a significant relationship with a child attending private coaching. Compared to below primary household head, the probability of child attending private tutoring increases as the education of the household head increases. Hence, the argument that less educated parents on average may be less able to help their children with homework and need to rely on outside tutoring instead does not seem to be supported by the evidence.

Turning to family size, having one sibling in age 6-24 increases the probability of private tutoring by 2.1 percentage points in 2007-08. However, this positive relationship is broken when number of siblings go up. This implies although private tutoring are within the financial means of smaller families, however, it becomes more difficult to bear the additional cost of private tutoring as number of school age child increases. The student is more likely to attend private tutoring as distance to the enrolled institution increases.

The family's economic status has a significant impact in the decision to send a child for private coaching. Compared to a child belonging to bottom $20 \%$ of population, the probability of a child attending private tutoring is 8.8 (4.5) percentage points higher if a child belongs to top $20 \%$ (quintile 4) of the population based on consumption expenditure. This pattern is observed at all stages of schooling (appendix Table A1): the probability of attending private tutoring increases as one moves to next higher quintile. 
Overall, the probability of private tutoring increase as the economic status and education of parents' increases. Similarly, the probability of private tutoring is higher in private schools, English medium schools, and at higher stages of schooling. Moreover, there exists evidence of pro-male bias in households' decision to enroll their child for private tutoring.

\subsection{Determinants of private tutoring expenditure}

Column (4), (5), and (6) of Table 4 presents the OLS results of determinants of private tutoring expenditure. Our dependent variable is log of expenditure on private tutoring. Only students with positive private tutoring expenditures are included in the estimation. Stage of schooling has a significant relationship with the amount spent on private tutoring. In 2007-08, compared to primary school, students at the middle school spend 21.4 percent more, students at the secondary and senior secondary school spend 52.5 and 76.3 percent more, respectively. Similarly, students at the tertiary level spend 50.8 percent more on private tutoring compared with students at primary stage. Similar patterns are observed in the 1987-88 and 1995-96 data. Presumably, the schooling stage pattern reflects the use of private tutoring to prepare for school leaving examinations, especially grade 10 and grade 12 at the end of secondary and senior secondary schools. Similar pattern is also observed in other countries, for example, in Egypt students in diploma-granting grades spend more on private tutoring (Assad and El-Badaway, 2004).

In 2007-08, students enrolled in private-aided schools spend 7.4 percent more on private tutoring compared with the students enrolled in government schools. Similarly, students in private-unaided schools spend 4.1 percent more. In 1995-96, students enrolled in privateunaided schools spend no different than students enrolled at the government schools, however, students at private-aided schools spend 7.5 percentage more than students at government schools. Thus, the households use some of the savings through less school

fees at private-aided schools compared to private schools on providing supplementary education. Students enrolled in English medium schools spend 24.8 percent more in 
2007-08 compared to students enrolled in non-English medium schools. Interestingly, in 1995-96, students at the English medium schools spent 14.7 percent less, while students at English-medium schools were more likely to take private tutoring in both 1995-96 and 2007-08.

A child enrolled for private tutoring in rural areas spend 28.5 percent less in 2007-08 on private tutoring compared with a child enrolled for private tutoring in urban areas. Tansel and Bircan (2006) finds that households who reside in urban areas (locations with population over 20,000 ) spend 66 percent more on private tutoring than households who reside in rural areas. Kim and Lee (2001) found a similar result in that those households who live in high-density residential development areas spent more on private tutoring in Korea.

There exist evidence of gender bias in how much to spend on private tutoring conditional on positive decision to take private tutoring. In 2007-08, a girl child is not only 2 percent less likely to attend private tutoring, but also households spend 2 percent less on a girl child compared to a boy child conditional on sending them to private coaching. Hence, pro-male bias exists in both stages of decision. Kingdon (2005) also have documented gender bias in the education expenditure in India. Pro-male bias in private tutoring expenditure has also been reported in Pakistan (Aslam and Atherton, 2011), however, the study in Viet Nam by Dang (2007) found no significant gender differences. Interestingly, the pro-male gender bias in private tutoring expenditure exists only at secondary and senior secondary levels (appendix Table A1) not at the primary and middle levels that implies conditional on sending a child to private tuition, parents spend same on private tuition irrespective of gender if child is in primary or secondary schools.

Students belonging to SC/ST are not only less likely to take private tutoring, but also likely to spend substantially less amount on private tutoring compared to non-SC/ST students. In 2007-08, SC (ST) students are likely to spend 11.2 (10.9) percent less than the non-SC/ST students. The disadvantage for STs in terms of expenditure seems to have 
declined over time, however in terms of enrollment in private tutoring, the disadvantage seems to have increased over time. In contrast, the disadvantage for SC students in terms of enrollment in private tutoring seems to be same, however in terms of private tutoring expenditure have increased.

Household head's education has a significant impact on household expenditure on private tutoring of a child. As discussed in the last section, the probability of a child attending private tutoring increases with the household head's education. Moreover, there exists a significant positive relationship between household head's education and amount spent on private coaching. Compared to a below primary educated head, as the education of head increases, the households' spend more on the private tutoring. For example, in 2007-08, a household with a secondary (tertiary) educated household head spend about 15.6 (29.2) percent more on a child's private tutoring compared to a household with only below primary educated household head. The higher level of private tutoring expenditure based on higher education level of head existed in earlier periods also.

Another interesting question is whether households with more children spend less per child? There exists a considerable literature on Quantity-Quality tradeoff which argues that investment in human capital decreases as the family size (number of children) increases. In India, Kugler and Kumar (2014) show that an extra child in the family reduces schooling by 0.1 years and reduces the probability of ever attending or being enrolled in school by between 1 and 2 percentage points, respectively. However, they do not consider the amount of investment in monetary terms. Lee (2008) and Kang (2010) use private tutoring expenditures of Korean parents as a proxy for educational investments. Kang (2010) finds that large (small) family size has a strong negative (positive) impact on educational investments for girls but little impact on those for boys. In Turkey and Vietnam also, the number of children in the household is negatively correlated with private tutoring expenditure (Tansel and Bircan, 2006; Dang, 2007). Our paper does not claim any causal relation between family size and investment in child. However, the results indicate that 
quantity-quality tradeoff appear only after a certain family size. For example, compared to having no sibling, having one sibling increase the probability of the taking private tutoring by 2.1 percentage points in 2007-08, however, it does not affect the amount spent on the private tutoring. Nevertheless, having two siblings reduces the amount spent on private tutoring by 3.5 percent compared to having no sibling. Having more than two siblings affect the probability of private tutoring and amount spent on private tutoring negatively.

The households' also spend more on private tutoring as distance to enrolled educational institution increases. The economic ability of a household plays an important role in determining not only the participation in private tutoring but also the amount spent on private tutoring. A household with higher total per capita consumption expenditure also spends more on private tutoring, after controlling for other variables ${ }^{17}$ As private tutoring expenditure, as well as household per capita expenditure, is in log form, the coefficient on household expenditure per capita can be roughly interpreted as the income elasticity of private tutoring. Our estimated elasticity in 2007-08 is 0.36: that is, holding other things constant, a $1 \%$ increase in household per capita consumption expenditure is associated with $0.36 \%$ increase in the expenditure on private tutoring per child. The elasticity estimate in 1987-88 data is also 0.36, however, in the 1995-96 data, the elasticity estimate is 0.59 . The Tobit model provide similar estimates for 2007-08 (Table 5): the unconditional marginal effect of 0.36 is the expenditure elasticity for all of the households while 0.39 is the expenditure elasticity for the households with positive private tutoring expenditures. Kim and Lee (2010) finds an estimated elasticity of 0.54 for the average household, while Psacharopoulous and Papakonstantinou (2005) finds demand for private tutoring highly inelastic in Greece. In contrast, Tansel and Bircan (2006) finds demand for

\footnotetext{
${ }^{17}$ The per capita consumption expenditure is taken as a proxy for per capita income. In the Engel curve literature, total expenditure is commonly used as a proxy for income for two reasons. First, total expenditure is considered to reflect permanent income better than income itself. Second, total expenditure is less prone to measurement errors compared to income.
} 
private tutoring to be unitary elastic in Turkey. We also estimated our models separately for different stages of schooling for 2007-08, and results are reported in appendix Table A1. The elasticity is less than one for all stages of schooling. The elasticity is 0.35 for primary level while it is 0.45 for senior secondary level. Hence households increase private tutoring expenditure more at higher level of schooling for the same $1 \%$ increase in household per capita consumption expenditure. Dang (2007) finds an elasticity of 0.53 for lower secondary and 0.43 for primary students in Vietnam.

\section{Conclusion}

This paper first documents the incidence and cost of private tutoring in India over time. Then it examines the factors that drive the decision to attend private tutoring, and conditional on attending private tutoring how much to spend on private tutoring. The concept of private tutoring is not a new development for India. A significant proportion of students attended private tutoring even in 1986-87. The prevalence of private tutoring has grown steadily over time.

This paper finds that private tutoring in India is a necessity at all stages of schooling, and there is a much higher probability of attending private tutoring at secondary and senior secondary levels. The evidence suggests that students with better family and socioeconomic backgrounds, living in urban areas are more likely to attend private tutoring. Similarly, students with better educated parents and from private schools are more likely to attend private tutoring. There is also a strong evidence of pro-male bias not only in the decision to enroll a child for private tutoring but also in how much to spend on private tutoring at the secondary and senior secondary levels.

From the evidence, it seems that private tutoring is less about remedial help for students to keep up with their peers, and much more about competition and creation of differentials. Given this, the existence and expansion of private tutoring has great 
implications for equality of opportunities and the government efforts towards creating a level field through mass provision of public education. 


\section{References}

[1] ASER Centre (2013). Annual Status of Education Report. New Delhi.

[2] Aslam, M and Atherton, P (2012). The Shadow Education Sector in India and Pakistan: The Determinants, Benefits and Equity Effects of Private Tutoring. ESP Working Paper Series, 38.

[3] Assad, R and El-Badawy, A (2004). Private and Group Tutoring in Egypt: Where Is the Gender Inequality? Paper presented at the Economic Research Forum 11th Annual Conference: Post Conflict Reconstruction, 14-16 December, Beirut, Lebanon

[4] Bray, M and Lykins, C (2011). Shadow Education: Private Supplementary Tutoring and Its Implications for Policy Makers in Asia. CERC Monograph Series in Comparative and International Education and Development, No. 9.

[5] Bray, M and Kwok, P (2003). Demand for Private Supplementary Tutoring: Conceptual Considerations, and Socio-economic Patterns in Hong Kong. Economics of Education Review, 22, 611-20.

[6] Briggs, D. C (2001). The Effect of Admissions Test Preparation: Evidence from NELS: 88. Chance, 14(1):10-18.

[7] Cameroon, A. C and Trivedi, P. K (2009). Microeconometrics Using Stata. Stata Press.

[8] Dang, H and Rogers, F. H (2008). The Growing Phenomenon of Private Tutoring: Does It Deepen Human Capital, Widen Inequalities, or Waste Resources? World Bank Research Observer, 23(2), 161-200.

[9] Dang, H (2007). The Determinants and Impact of Private Tutoring Classes in Vietnam. Economics of Education Review, 26(6), 684-99. 
[10] Dongre, A and Tewary, V (2014). Impact of Private Tutoring on Learning Levels: Evidence from India. AI Working Paper Series.

[11] Gurun, A and Millimet, D. L (2008). Does Private Tutoring Payoff? IZA Discussion Paper, 3637.

[12] Jayachandran, S (2014). Incentives to teach badly: After-school tutoring in developing countries. Journal of Development Economics, doi:10.1016/j.jdeveco.2014.02.008.

[13] Kang, C (2007). Does Money Matter? The Effect of Private Educational Expenditures on Academic Performance. Working Paper No. 0704, National University of Singapore, Department of Economics.

[14] Kim, S and Lee, J (2010). Private Tutoring and Demand for Education in South Korea. Economic Development and Cultural Change, 58(2), 259-96.

[15] Kingdon, G (2005). Where Has All the Bias Gone? Detecting Gender Bias in the Intrahousehold Allocation of Educational Expenditure. Economic Development and Cultural Change, 53(2), 409-51.

[16] Kugler, A and Kumar, S (2014). Preference for Boys, Family Size and Educational Attainment in India. Mimeo, Sam Houston University.

[17] Madan, D (2008). Sample selection versus two-part models revisited: The case of female smoking and drinking. Journal of Health Economics, 27, 300-307.

[18] Ono, H (2007). Does Examination Hell Pay Off? A Cost-Benefit Analysis of "Ronin" and College Education in Japan. Economics of Education Review, 26(3):271-84.

[19] Sujatha, K. (2014). Private tuition in India: trends and issues. Revue internationale d'éducation de Sèvres [En ligne], Colloque : L'éducation en Asie en 2014 : Quels enjeux mondiaux?, URL : http://ries.revues.org/3913 
[20] Tansel, A and Bircan, F (2006). Demand for Education in Turkey: A Tobit Analysis of Private Tutoring Expenditures. Economics of Education Review, 25(3): 303-313.

[21] Wooldridge, J (2010), Econometric Analysis of Cross Section and Panel Data. The MIT Press, 2nd edition. 
Table 1: Sample Descriptive

\begin{tabular}{lrrr}
\hline & $1986-87$ & $1995-96$ & $2007-08$ \\
\cline { 2 - 4 } Total number of household surveyed & 77,011 & 72,883 & 100,581 \\
Total number of persons surveyed & 430,662 & 371,608 & 445,960 \\
Total in age group (6-24) & 191,254 & 153,256 & 160,076 \\
Currently Attending in age group (6-24) & 96,601 & 91,407 & 92,349 \\
Education expenditure reported age 6-24 \& attending & $\mathbf{9 3 , 5 1 6}$ & $\mathbf{8 9 , 9 7 9}$ & $\mathbf{9 1 , 2 9 4}$ \\
\hline
\end{tabular}


Table 2: Proportion of students in age group (6-24) attending private tutoring by stage of schooling

\begin{tabular}{|c|c|c|c|c|c|c|c|c|c|}
\hline & 1986-87 & $1995-96$ & $2007-08$ & 1986-87 & $1995-96$ & $2007-08$ & 1986-87 & $1995-96$ & 2007-08 \\
\hline \multicolumn{10}{|c|}{ a. By area or residence } \\
\hline & \multicolumn{6}{|c|}{ Urban } & \multicolumn{3}{|c|}{ All } \\
\hline Primary & 7.52 & 9.08 & 11.24 & 17.32 & 22.61 & 21.78 & 10.09 & 12.36 & 13.45 \\
\hline Middle & 14.46 & 17.47 & 17.17 & 24.22 & 30.01 & 28.34 & 17.54 & 21.40 & 19.94 \\
\hline Secondary & 27.00 & 28.62 & 26.55 & 36.31 & 41.79 & 40.35 & 30.26 & 33.28 & 30.46 \\
\hline Sr. Secondary & 21.99 & 24.13 & 25.03 & 27.53 & 33.87 & 41.24 & 24.74 & 28.68 & 31.16 \\
\hline Tertiary & 18.91 & 14.44 & 16.43 & 17.53 & 21.24 & 20.20 & 17.98 & 18.83 & 18.39 \\
\hline All & 12.12 & 13.86 & 15.65 & 22.55 & 27.95 & 27.74 & 15.34 & 18.09 & 18.81 \\
\hline \multicolumn{10}{|c|}{ b. By school type } \\
\hline & \multicolumn{3}{|c|}{ Private-unaided } & \multicolumn{3}{|c|}{ Private-aided } & \multicolumn{3}{|c|}{ Government } \\
\hline Primary & 17.71 & 19.29 & 16.88 & & 22.89 & 19.22 & 8.13 & 9.83 & 11.98 \\
\hline Middle & 21.96 & 24.17 & 21.34 & & 30.26 & 25.16 & 15.53 & 18.12 & 18.68 \\
\hline Secondary & 32.07 & 36.92 & 31.56 & & 40.98 & 32.09 & 29.07 & 29.39 & 29.62 \\
\hline Sr. Secondary & 26.27 & 27.88 & 29.79 & & 34.84 & 33.30 & 23.31 & 25.27 & 30.82 \\
\hline Tertiary & 21.38 & 19.60 & 11.40 & & 20.13 & 16.43 & 14.35 & 17.83 & 22.80 \\
\hline All & 22.38 & 22.19 & 20.23 & & 29.52 & 24.76 & 12.63 & 14.63 & 17.29 \\
\hline \multicolumn{10}{|c|}{ c. By social group } \\
\hline & \multicolumn{3}{|c|}{ Scheduled Tribes } & \multicolumn{3}{|c|}{ Scheduled Castes } & \multicolumn{3}{|c|}{ Others } \\
\hline Primary & 4.06 & 4.74 & 5.81 & 7.99 & 9.77 & 11.78 & 10.99 & 13.90 & 14.98 \\
\hline Middle & 8.59 & 9.92 & 9.25 & 12.76 & 18.44 & 17.52 & 18.95 & 22.91 & 21.89 \\
\hline Secondary & 18.45 & 17.79 & 17.99 & 24.36 & 29.57 & 25.86 & 31.83 & 35.09 & 32.60 \\
\hline Sr. Secondary & 19.89 & 26.72 & 18.28 & 27.37 & 23.93 & 25.41 & 24.65 & 29.54 & 33.12 \\
\hline Tertiary & 11.02 & 6.57 & 17.33 & 16.47 & 14.75 & 17.80 & 18.36 & 19.80 & 18.53 \\
\hline All & 7.11 & 8.01 & 8.78 & 11.60 & 14.24 & 15.95 & 16.58 & 19.91 & 20.69 \\
\hline \multicolumn{10}{|c|}{ d. By Gender } \\
\hline & \multicolumn{3}{|c|}{ Boys } & \multicolumn{3}{|c|}{ Girls } & \multicolumn{3}{|c|}{ ALL } \\
\hline Primary & 10.15 & 12.71 & 14.00 & 10.00 & 11.88 & 12.79 & 10.09 & 12.36 & 13.45 \\
\hline Middle & 17.50 & 21.67 & 20.84 & 17.63 & 20.98 & 18.81 & 17.55 & 21.40 & 19.94 \\
\hline Secondary & 30.71 & 33.15 & 32.60 & 29.20 & 33.50 & 27.58 & 30.26 & 33.28 & 30.46 \\
\hline Sr. Secondary & 25.41 & 28.51 & 32.58 & 23.11 & 28.98 & 29.06 & 24.74 & 28.68 & 31.16 \\
\hline Tertiary & 18.93 & 19.62 & 18.82 & 16.03 & 17.54 & 17.81 & 17.98 & 18.83 & 18.39 \\
\hline All & 15.89 & 18.70 & 19.88 & 14.38 & 17.20 & 17.46 & 15.34 & 18.09 & 18.81 \\
\hline \multicolumn{10}{|c|}{ e. By quintile based household per capita consumption expenditure } \\
\hline & \multicolumn{3}{|c|}{ Quintile 1} & \multicolumn{3}{|c|}{ Quintile 3} & \multicolumn{3}{|c|}{ Quintile 5} \\
\hline Primary & 6.59 & 5.13 & 10.33 & 9.28 & 14.28 & 13.66 & 15.72 & 18.62 & 19.82 \\
\hline Middle & 11.25 & 12.05 & 14.01 & 16.87 & 19.86 & 19.65 & 23.28 & 27.87 & 28.44 \\
\hline Secondary & 21.97 & 15.81 & 21.58 & 27.47 & 28.28 & 29.71 & 37.80 & 41.77 & 38.80 \\
\hline Sr. Secondary & 18.64 & 13.54 & 19.18 & 21.56 & 17.92 & 31.81 & 29.44 & 36.28 & 36.77 \\
\hline Tertiary & 15.26 & 5.74 & 14.02 & 19.72 & 16.01 & 18.94 & 18.84 & 21.13 & 19.21 \\
\hline All & 9.32 & 7.19 & 12.56 & 13.82 & 17.39 & 18.81 & 22.83 & 26.90 & 26.87 \\
\hline
\end{tabular}

Note: in 1987-88 data, schools are classified in two categories private vs. government, hence private unaided include all private. 
Table 3: Per child (academic year) average cost of private tutoring (6-24 age group) in Indian Rupees at 2007-08 prices

\begin{tabular}{|c|c|c|c|c|c|c|c|}
\hline & & \multicolumn{3}{|c|}{ All currently attending school } & \multicolumn{3}{|c|}{$\begin{array}{c}\text { Currently taking private } \\
\text { coaching }\end{array}$} \\
\hline & & 1986-87 & 1995-96 & $2007-08$ & 1986-87 & $1995-96$ & $2007-08$ \\
\hline \multirow[t]{3}{*}{ Primary } & Average private tutoring expenditure & 76.08 & 106.63 & 129.66 & 754.02 & 862.95 & 964.02 \\
\hline & $\%$ of private education expenditure & 5.01 & 5.71 & 6.41 & 49.27 & 45.87 & 47.48 \\
\hline & $\%$ of household per capita expenditure & 0.98 & 0.98 & 1.40 & 9.76 & 7.90 & 10.43 \\
\hline \multirow[t]{3}{*}{ Middle } & Average private tutoring expenditure & 186.87 & 272.19 & 283.45 & 1065.32 & 1271.63 & 1421.81 \\
\hline & $\%$ of private education expenditure & 6.94 & 8.16 & 8.34 & 39.43 & 37.93 & 41.72 \\
\hline & $\%$ of household per capita expenditure & 2.37 & 2.29 & 2.75 & 13.47 & 10.69 & 13.78 \\
\hline \multirow[t]{3}{*}{ Secondary } & Average private tutoring expenditure & 476.21 & 610.86 & 680.72 & 1573.85 & 1835.68 & 2234.53 \\
\hline & $\%$ of private education expenditure & 11.92 & 13.07 & 12.47 & 39.30 & 39.12 & 40.88 \\
\hline & $\%$ of household per capita expenditure & 5.62 & 4.83 & 6.03 & 18.54 & 14.53 & 19.78 \\
\hline \multirow[t]{3}{*}{ Sr. Secondary } & Average private tutoring expenditure & 595.76 & 916.46 & 1258.95 & 2407.97 & 3195.52 & 4040.38 \\
\hline & $\%$ of private education expenditure & 9.77 & 11.63 & 12.56 & 39.47 & 40.08 & 40.30 \\
\hline & $\%$ of household per capita expenditure & 7.07 & 5.73 & 8.90 & 28.57 & 19.97 & 28.56 \\
\hline \multirow[t]{3}{*}{ Tertiary } & Average private tutoring expenditure & 453.14 & 653.81 & 724.41 & 2520.08 & 3472.95 & 3938.16 \\
\hline & $\%$ of private education expenditure & 6.51 & 7.33 & 5.86 & 36.09 & 38.79 & 31.82 \\
\hline & $\%$ of household per capita expenditure & 4.32 & 3.68 & 4.65 & 23.99 & 19.56 & 25.28 \\
\hline \multirow[t]{3}{*}{ All } & Average private tutoring expenditure & 189.42 & 273.00 & 361.58 & 1234.70 & 1509.01 & 1922.24 \\
\hline & $\%$ of private education expenditure & 6.62 & 7.54 & 8.07 & 42.91 & 41.43 & 42.77 \\
\hline & $\%$ of household per capita expenditure & 2.30 & 2.11 & 3.09 & 14.96 & 11.69 & 16.45 \\
\hline
\end{tabular}


Table 4: Students demand for private tutoring (age 6-24), Hurdle model

\begin{tabular}{|c|c|c|c|c|c|c|}
\hline \multirow{3}{*}{$\begin{array}{l}\text { Dependent variable } \\
\text { Estimation method }\end{array}$} & \multicolumn{3}{|c|}{$\begin{array}{c}\text { Attend private tutoring }=1 ; \text { Not attend } \\
\text { private coaching=0 }\end{array}$} & \multicolumn{3}{|c|}{$\begin{array}{l}\text { Log of private tutoring expenditure } \\
\text { condition on attending private coaching }\end{array}$} \\
\hline & \multicolumn{3}{|c|}{ OLS } & \multicolumn{3}{|c|}{ OLS } \\
\hline & (1) & (2) & (3) & (4) & (5) & (6) \\
\hline \multicolumn{7}{|c|}{ Reference: Attending Primary School } \\
\hline Attending Middle School & $\begin{array}{c}0.049 * * * \\
(0.004)\end{array}$ & $\begin{array}{c}0.052 * * * \\
(0.006)\end{array}$ & $\begin{array}{c}0.049 * * * \\
(0.005)\end{array}$ & $\begin{array}{c}0.230 * * * \\
(0.021)\end{array}$ & $\begin{array}{c}0.207 * * * \\
(0.017)\end{array}$ & $\begin{array}{c}0.214 * * * \\
(0.018)\end{array}$ \\
\hline Attending Secondary School & $\begin{array}{c}0.153 * * * \\
(0.007)\end{array}$ & $\begin{array}{c}0.146 * * * \\
(0.009)\end{array}$ & $\begin{array}{c}0.137 * * * \\
(0.007)\end{array}$ & $\begin{array}{c}0.526 * * * \\
(0.029)\end{array}$ & $\begin{array}{c}0.438 * * * \\
(0.024)\end{array}$ & $\begin{array}{c}0.525 * * * \\
(0.026)\end{array}$ \\
\hline Attending Sr. Secondary School & $\begin{array}{c}0.071 * * * \\
(0.010)\end{array}$ & $\begin{array}{c}0.073 * * * \\
(0.013)\end{array}$ & $\begin{array}{c}0.125 * * * \\
(0.010)\end{array}$ & $\begin{array}{c}0.628 * * * \\
(0.040)\end{array}$ & $\begin{array}{c}0.618 * * * \\
(0.032)\end{array}$ & $\begin{array}{c}0.763 * * * \\
(0.033)\end{array}$ \\
\hline Attending Tertiary level & $\begin{array}{l}-0.022 * \\
(0.013)\end{array}$ & $\begin{array}{c}-0.061 * * * \\
(0.014)\end{array}$ & $\begin{array}{c}-0.049 * * * \\
(0.012)\end{array}$ & $\begin{array}{c}0.474 * * * \\
(0.056)\end{array}$ & $\begin{array}{c}0.419 * * * \\
(0.044)\end{array}$ & $\begin{array}{c}0.508 * * * \\
(0.045)\end{array}$ \\
\hline Rural & $\begin{array}{c}-0.091 * * * \\
(0.004)\end{array}$ & $\begin{array}{c}-0.139 * * * \\
(0.005)\end{array}$ & $\begin{array}{c}-0.096 * * * \\
(0.004)\end{array}$ & $\begin{array}{c}-0.269 * * * \\
(0.017)\end{array}$ & $\begin{array}{c}-0.239 * * * \\
(0.014)\end{array}$ & $\begin{array}{c}-0.285^{* * *} \\
(0.014)\end{array}$ \\
\hline Child's gender-Female & $\begin{array}{c}-0.030 * * * \\
(0.003)\end{array}$ & $\begin{array}{c}-0.024 * * * \\
(0.004)\end{array}$ & $\begin{array}{c}-0.020 * * * \\
(0.003)\end{array}$ & $\begin{array}{c}-0.045^{* * *} \\
(0.014)\end{array}$ & $\begin{array}{c}-0.076 * * * \\
(0.011)\end{array}$ & $\begin{array}{c}-0.027 * * * \\
(0.010)\end{array}$ \\
\hline Child's age & $\begin{array}{c}0.001 \\
(0.001)\end{array}$ & $\begin{array}{l}0.002^{*} \\
(0.001)\end{array}$ & $\begin{array}{l}0.001 * \\
(0.001)\end{array}$ & $\begin{array}{c}0.035 * * * \\
(0.003)\end{array}$ & $\begin{array}{c}0.045^{* * *} \\
(0.003)\end{array}$ & $\begin{array}{c}0.033 * * * \\
(0.003)\end{array}$ \\
\hline \multicolumn{7}{|l|}{ Reference: Government School } \\
\hline Private-unaided & $\begin{array}{c}0.034 * * * \\
(0.004)\end{array}$ & $\begin{array}{c}0.036 * * * \\
(0.008)\end{array}$ & $\begin{array}{c}0.016 * * * \\
(0.006)\end{array}$ & $\begin{array}{c}0.105 * * * \\
(0.017)\end{array}$ & $\begin{array}{l}-0.017 \\
(0.022)\end{array}$ & $\begin{array}{c}0.041 * * \\
(0.020)\end{array}$ \\
\hline Private-Aided & - & $\begin{array}{c}0.038 * * * \\
(0.006)\end{array}$ & $\begin{array}{c}0.040 * * * \\
(0.006)\end{array}$ & - & $\begin{array}{c}0.075 * * * \\
(0.015)\end{array}$ & $\begin{array}{c}0.074 * * * \\
(0.018)\end{array}$ \\
\hline Medium of instruction is English & - & $\begin{array}{c}0.025 * * * \\
(0.008)\end{array}$ & $\begin{array}{c}0.014 * * \\
(0.007)\end{array}$ & - & $\begin{array}{c}-0.147 * * * \\
(0.019)\end{array}$ & $\begin{array}{c}0.248 * * * \\
(0.018)\end{array}$ \\
\hline \multicolumn{7}{|c|}{ Reference: Others (General and OBCs) } \\
\hline Scheduled Castes & $\begin{array}{c}-0.026 * * * \\
(0.004)\end{array}$ & $\begin{array}{c}-0.024 * * * \\
(0.004)\end{array}$ & $\begin{array}{c}-0.022 * * * \\
(0.003)\end{array}$ & $\begin{array}{c}-0.063 * * * \\
(0.022)\end{array}$ & $\begin{array}{c}-0.059 * * * \\
(0.016)\end{array}$ & $\begin{array}{c}-0.109 * * * \\
(0.014)\end{array}$ \\
\hline Scheduled Tribes & $\begin{array}{c}-0.031 * * * \\
(0.006)\end{array}$ & $\begin{array}{c}-0.023 * * * \\
(0.008)\end{array}$ & $\begin{array}{c}-0.055^{* * *} \\
(0.005)\end{array}$ & $\begin{array}{c}-0.174 * * * \\
(0.046)\end{array}$ & $\begin{array}{c}-0.126 * * * \\
(0.036)\end{array}$ & $\begin{array}{c}-0.112 * * * \\
(0.029)\end{array}$ \\
\hline \multicolumn{7}{|c|}{ Reference: Head-below primary educated } \\
\hline Head-primary educated & $\begin{array}{c}0.020 * * * \\
(0.004)\end{array}$ & $\begin{array}{l}0.008^{*} \\
(0.005)\end{array}$ & $\begin{array}{c}0.013 * * * \\
(0.004)\end{array}$ & $\begin{array}{c}0.079 * * * \\
(0.020)\end{array}$ & $\begin{array}{c}0.064 * * * \\
(0.017)\end{array}$ & $\begin{array}{c}0.035 * * \\
(0.016)\end{array}$ \\
\hline Head-middle educated & $\begin{array}{c}0.044 * * * \\
(0.005)\end{array}$ & $\begin{array}{c}0.020 * * * \\
(0.005)\end{array}$ & $\begin{array}{c}0.027 * * * \\
(0.004)\end{array}$ & $\begin{array}{c}0.163 * * * \\
(0.021)\end{array}$ & $\begin{array}{c}0.147 * * * \\
(0.016)\end{array}$ & $\begin{array}{c}0.107 * * * \\
(0.015)\end{array}$ \\
\hline Head-secondary educated & $\begin{array}{c}0.055 * * * \\
(0.006)\end{array}$ & $\begin{array}{c}0.025 * * * \\
(0.007)\end{array}$ & $\begin{array}{c}0.044 * * * \\
(0.005)\end{array}$ & $\begin{array}{c}0.222 * * * \\
(0.024)\end{array}$ & $\begin{array}{c}0.155^{* * *} \\
(0.019)\end{array}$ & $\begin{array}{c}0.156^{* * *} \\
(0.018)\end{array}$ \\
\hline Head-Sr. Secondary educated & $\begin{array}{c}0.037 * * * \\
(0.007)\end{array}$ & $\begin{array}{c}0.027 * * * \\
(0.009)\end{array}$ & $\begin{array}{c}0.045^{* * * *} \\
(0.007)\end{array}$ & $\begin{array}{c}0.272 * * * \\
(0.029)\end{array}$ & $\begin{array}{c}0.273 * * * \\
(0.023)\end{array}$ & $\begin{array}{c}0.236 * * * \\
(0.021)\end{array}$ \\
\hline Head-tertiary educated & $\begin{array}{c}0.025 * * * \\
(0.008)\end{array}$ & $\begin{array}{l}0.019 * * \\
(0.009)\end{array}$ & $\begin{array}{c}0.040^{* * *} \\
(0.008)\end{array}$ & $\begin{array}{c}0.418^{* * *} \\
(0.030)\end{array}$ & $\begin{array}{c}0.249 * * * \\
(0.022)\end{array}$ & $\begin{array}{c}0.292 * * * \\
(0.021)\end{array}$ \\
\hline
\end{tabular}




\begin{tabular}{|c|c|c|c|c|c|c|}
\hline Head is female & $\begin{array}{c}0.006 \\
(0.006)\end{array}$ & $\begin{array}{c}-0.014 * * \\
(0.007)\end{array}$ & $\begin{array}{c}0.003 \\
(0.005)\end{array}$ & $\begin{array}{l}0.050 * \\
(0.027)\end{array}$ & $\begin{array}{c}0.106 * * * \\
(0.023)\end{array}$ & $\begin{array}{c}0.019 \\
(0.019)\end{array}$ \\
\hline \multicolumn{7}{|l|}{ Reference: No sibling in 6-24 age group } \\
\hline Number of sibling in age $6-24$ is one & $\begin{array}{c}0.010 \\
(0.006)\end{array}$ & $\begin{array}{c}0.015 * * \\
(0.007)\end{array}$ & $\begin{array}{c}0.021 * * * \\
(0.005)\end{array}$ & $\begin{array}{c}0.096 * * * \\
(0.025)\end{array}$ & $\begin{array}{c}0.029 \\
(0.018)\end{array}$ & $\begin{array}{l}-0.004 \\
(0.014)\end{array}$ \\
\hline Number of sibling in age $6-24$ is two & $\begin{array}{c}0.009 \\
(0.006)\end{array}$ & $\begin{array}{l}-0.001 \\
(0.007)\end{array}$ & $\begin{array}{l}-0.001 \\
(0.005)\end{array}$ & $\begin{array}{c}0.078 * * * \\
(0.025)\end{array}$ & $\begin{array}{c}0.019 \\
(0.019)\end{array}$ & $\begin{array}{c}-0.035^{* *} \\
(0.016)\end{array}$ \\
\hline Number of sibling in age 6-24 is three & $\begin{array}{l}-0.002 \\
(0.006)\end{array}$ & $\begin{array}{l}-0.009 \\
(0.008)\end{array}$ & $\begin{array}{c}-0.021 * * * \\
(0.005)\end{array}$ & $\begin{array}{c}0.058 * * \\
(0.026)\end{array}$ & $\begin{array}{c}0.029 \\
(0.021)\end{array}$ & $\begin{array}{c}-0.047 * * \\
(0.021)\end{array}$ \\
\hline $\begin{array}{l}\text { Number of sibling in age } 6-24 \text { is four } \\
\text { and more }\end{array}$ & $\begin{array}{l}-0.001 \\
(0.006)\end{array}$ & $\begin{array}{c}-0.016 * * \\
(0.008)\end{array}$ & $\begin{array}{c}-0.019 * * * \\
(0.005)\end{array}$ & $\begin{array}{c}0.116 * * * \\
(0.027)\end{array}$ & $\begin{array}{l}-0.000 \\
(0.022)\end{array}$ & $\begin{array}{l}-0.021 \\
(0.024)\end{array}$ \\
\hline Log of school tuition fees* & $\begin{array}{l}-0.001 \\
(0.003)\end{array}$ & $\begin{array}{c}-0.014 * * * \\
(0.003)\end{array}$ & $\begin{array}{c}0.001 \\
(0.002)\end{array}$ & $\begin{array}{c}0.144 * * * \\
(0.013)\end{array}$ & $\begin{array}{c}0.108 * * * \\
(0.008)\end{array}$ & $\begin{array}{c}0.089 * * * \\
(0.008)\end{array}$ \\
\hline \multicolumn{7}{|c|}{ Reference: Distance to institute is less than $1 \mathbf{~ k m}$} \\
\hline Distance to institute is $1-2 \mathrm{kms}$ & $\begin{array}{l}0.009 * * \\
(0.004)\end{array}$ & & $\begin{array}{c}0.012 * * * \\
(0.004)\end{array}$ & $\begin{array}{l}0.037 * * \\
(0.019)\end{array}$ & & $\begin{array}{c}0.070 * * * \\
(0.014)\end{array}$ \\
\hline Distance to institute is $2-5 \mathrm{kms}$ & $\begin{array}{l}0.017 * * * \\
(0.005)\end{array}$ & & $\begin{array}{c}0.014 * * * \\
(0.005)\end{array}$ & $\begin{array}{c}0.075 * * * \\
(0.019)\end{array}$ & & $\begin{array}{c}0.103 * * * \\
(0.015)\end{array}$ \\
\hline Distance to institute is $>5 \mathrm{kms}$ & $\begin{array}{c}0.014 * * \\
(0.006)\end{array}$ & & $\begin{array}{l}-0.006 \\
(0.006)\end{array}$ & $\begin{array}{c}0.128 * * * \\
(0.025)\end{array}$ & & $\begin{array}{c}0.199 * * * \\
(0.019)\end{array}$ \\
\hline \multicolumn{7}{|l|}{ Reference: Poorest $20 \%$ of population } \\
\hline Quintile-2 & $\begin{array}{c}0.012 * * * \\
(0.005)\end{array}$ & $\begin{array}{c}0.045 * * * \\
(0.005)\end{array}$ & $\begin{array}{c}0.023 * * * \\
(0.004)\end{array}$ & & & \\
\hline Quintile-3 & $\begin{array}{c}0.028 * * * \\
(0.004)\end{array}$ & $\begin{array}{c}0.077 * * * \\
(0.006)\end{array}$ & $\begin{array}{c}0.045^{* * * *} \\
(0.004)\end{array}$ & & & \\
\hline Quintile-4 & $\begin{array}{c}0.050 * * * \\
(0.005)\end{array}$ & $\begin{array}{c}0.107 * * * \\
(0.006)\end{array}$ & $\begin{array}{c}0.058 * * * \\
(0.004)\end{array}$ & & & \\
\hline Quintile-5 & $\begin{array}{c}0.091 * * * \\
(0.005)\end{array}$ & $\begin{array}{c}0.166 * * * \\
(0.007)\end{array}$ & $\begin{array}{c}0.088 * * * \\
(0.006)\end{array}$ & & & \\
\hline $\begin{array}{l}\text { Log of per capita consumption } \\
\text { expenditure }\end{array}$ & & & & $\begin{array}{c}0.334 * * * \\
(0.015)\end{array}$ & $\begin{array}{c}0.591 * * * \\
(0.017)\end{array}$ & $\begin{array}{c}0.356 * * * \\
(0.014)\end{array}$ \\
\hline Constant & $\begin{array}{l}0.102 * * * \\
(0.016)\end{array}$ & $\begin{array}{c}0.198 * * * \\
(0.021)\end{array}$ & $\begin{array}{c}0.154 * * * \\
(0.016)\end{array}$ & $\begin{array}{c}1.179 * * * \\
(0.134)\end{array}$ & $\begin{array}{l}-0.250 * \\
(0.150)\end{array}$ & $\begin{array}{c}2.448 * * * \\
(0.132)\end{array}$ \\
\hline Observations & 92,630 & 89,555 & 90,584 & 15,307 & 18,162 & 19,208 \\
\hline R-squared & 0.180 & 0.260 & 0.309 & 0.440 & 0.567 & 0.598 \\
\hline
\end{tabular}

Note: All the models include district fixed effects. In the 1987-88 data, the schools are classified in only two categories: private and government, and the medium of instruction is also not reported. 
Table 5: Tobit estimation results and marginal effects for private tutoring expenditures (age 6-24), 2007-08

\begin{tabular}{|c|c|c|c|}
\hline & Tobit & $\begin{array}{c}\text { Marginal impacts } \\
\text { conditional on } \\
\text { uncensored }\end{array}$ & $\begin{array}{l}\text { Marginal effects } \\
\text { unconditional }\end{array}$ \\
\hline & $(1)$ & $(2)$ & $(3)$ \\
\hline \multicolumn{4}{|l|}{ Reference: Attending Primary School } \\
\hline Attending Middle School & $\begin{array}{c}1.806 * * * \\
(0.131)\end{array}$ & $\begin{array}{c}0.394 * * * \\
(0.030)\end{array}$ & $\begin{array}{c}0.359 * * * \\
(0.029)\end{array}$ \\
\hline Attending Secondary School & $\begin{array}{c}4.125 * * * \\
(0.184)\end{array}$ & $\begin{array}{c}0.986 * * * \\
(0.050)\end{array}$ & $\begin{array}{c}1.007 * * * \\
(0.058)\end{array}$ \\
\hline Attending Sr. Secondary School & $\begin{array}{c}3.662 * * * \\
(0.238)\end{array}$ & $\begin{array}{c}0.875 * * * \\
(0.064)\end{array}$ & $\begin{array}{c}0.895 * * * \\
(0.075)\end{array}$ \\
\hline Attending Tertiary level & $\begin{array}{c}-0.989 * * * \\
(0.313)\end{array}$ & $\begin{array}{c}-0.200 * * * \\
(0.061)\end{array}$ & $\begin{array}{c}-0.163 * * * \\
(0.047)\end{array}$ \\
\hline Female & $\begin{array}{c}-0.679 * * * \\
(0.074)\end{array}$ & $\begin{array}{c}-0.142 * * * \\
(0.015)\end{array}$ & $\begin{array}{c}-0.121 * * * \\
(0.013)\end{array}$ \\
\hline Age (Years) & $\begin{array}{c}0.069 * * * \\
(0.023)\end{array}$ & $\begin{array}{c}0.014 * * * \\
(0.005)\end{array}$ & $\begin{array}{c}0.012 * * * \\
(0.004)\end{array}$ \\
\hline \multicolumn{4}{|l|}{ Reference: Government School } \\
\hline Private-unaided & $\begin{array}{c}0.948 * * * \\
(0.132)\end{array}$ & $\begin{array}{c}0.203^{* * * *} \\
(0.029)\end{array}$ & $\begin{array}{c}0.181 * * * \\
(0.027)\end{array}$ \\
\hline Private-aided & $\begin{array}{c}1.601 * * * \\
(0.118)\end{array}$ & $\begin{array}{c}0.352 * * * \\
(0.027)\end{array}$ & $\begin{array}{c}0.325^{* * *} \\
(0.027)\end{array}$ \\
\hline Medium of instruction is English & $\begin{array}{c}0.667 * * * \\
(0.130)\end{array}$ & $\begin{array}{c}0.142 * * * \\
(0.028)\end{array}$ & $\begin{array}{c}0.126 * * * \\
(0.026)\end{array}$ \\
\hline Rural & $\begin{array}{c}-0.488 * * * \\
(0.096)\end{array}$ & $\begin{array}{c}-0.103 * * * \\
(0.020)\end{array}$ & $\begin{array}{c}-0.090 * * * \\
(0.018)\end{array}$ \\
\hline \multicolumn{4}{|l|}{ Reference: Others } \\
\hline Scheduled Castes & $\begin{array}{c}-0.944 * * * \\
(0.101)\end{array}$ & $\begin{array}{c}-0.193 * * * \\
(0.020)\end{array}$ & $\begin{array}{c}-0.160 * * * \\
(0.016)\end{array}$ \\
\hline Scheduled Tribes & $\begin{array}{c}-3.852 * * * \\
(0.187)\end{array}$ & $\begin{array}{c}-0.711 * * * \\
(0.030)\end{array}$ & $\begin{array}{c}-0.502 * * * \\
(0.017)\end{array}$ \\
\hline \multicolumn{4}{|l|}{ Reference: Head-below primary } \\
\hline Head-primary educated & $\begin{array}{c}0.488 * * * \\
(0.114)\end{array}$ & $\begin{array}{c}0.104 * * * \\
(0.024)\end{array}$ & $\begin{array}{c}0.091 * * * \\
(0.022)\end{array}$ \\
\hline Head-middle educated & $\begin{array}{c}1.170 * * * \\
(0.109)\end{array}$ & $\begin{array}{c}0.253 * * * \\
(0.024)\end{array}$ & $\begin{array}{c}0.228 * * * \\
(0.023)\end{array}$ \\
\hline Head-secondary educated & $\begin{array}{c}1.434 * * * \\
(0.125)\end{array}$ & $\begin{array}{c}0.315^{* * *} \\
(0.029)\end{array}$ & $\begin{array}{c}0.289 * * * \\
(0.028)\end{array}$ \\
\hline Head-Sr. Secondary educated & $\begin{array}{c}1.448 * * * \\
(0.150)\end{array}$ & $\begin{array}{c}0.319 * * * \\
(0.035)\end{array}$ & $\begin{array}{c}0.295 * * * \\
(0.034)\end{array}$ \\
\hline Head-tertiary educated & $\begin{array}{c}0.970 * * * \\
(0.155)\end{array}$ & $\begin{array}{c}0.210 * * * \\
(0.035)\end{array}$ & $\begin{array}{c}0.190 * * * \\
(0.033)\end{array}$ \\
\hline Head is female & $\begin{array}{c}0.107 \\
(0.132)\end{array}$ & $\begin{array}{c}0.022 \\
(0.028)\end{array}$ & $\begin{array}{c}0.019 \\
(0.024)\end{array}$ \\
\hline Number of sibling in age 6-24 is one & $\begin{array}{c}0.518 * * * \\
(0.110)\end{array}$ & $\begin{array}{c}0.109 * * * \\
(0.023)\end{array}$ & $\begin{array}{c}0.095 * * * \\
(0.021)\end{array}$ \\
\hline Number of sibling in age $6-24$ is two & -0.150 & -0.031 & -0.027 \\
\hline
\end{tabular}




$\begin{array}{lccc} & (0.120) & (0.025) & (0.021) \\ \text { Number of sibling in age 6-24 is three } & -0.869^{* * *} & -0.178^{* * *} & -0.148^{* * *} \\ & (0.143) & (0.029) & (0.023) \\ \text { Number of sibling in age 6-24 is four and } & -1.176^{* * *} & -0.237^{* * *} & -0.194 * * * \\ \text { more } & (0.161) & (0.031) & (0.024) \\ & -0.027 & -0.006 & -0.005 \\ \text { Log of school tuition fees } & (0.050) & (0.010) & (0.009) \\ & & & \\ \text { Reference: Distance less than 1 km } & 0.219^{* *} & 0.046^{* *} & 0.040^{* *} \\ \text { Distance to institute is 1-2 kms } & (0.106) & 0.072 * * * & (0.020) \\ & 0.339^{* * *} & (0.023) & 0.063^{* * *} \\ \text { Distance to institute is } 2-5 \mathrm{kms} & (0.108) & -0.019 & (0.020) \\ & -0.093 & (0.028) & -0.017 \\ \text { Distance to institute is }>5 \mathrm{kms} & (0.135) & 0.476^{* * *} & (0.024) \\ & 2.275^{* * *} & (0.019) & 0.410^{* * *} \\ \text { Log of per capita consumption expenditure } & (0.093) & & (0.017) \\ \text { Constant } & -35.760^{* * *} & & \end{array}$

Observations

90,579

90,579

90,579

Note: 71371 left-censored observations at lpvtcoach1<=0; 19208 uncensored observations; 0 rightcensored observations. Note: The model include state fixed effects. 
Appendix Table A1: Students demand for private tutoring (age 6-24), Hurdle model by stages of schooling 2007-08

\begin{tabular}{|c|c|c|c|c|c|c|c|c|c|c|}
\hline \multirow[t]{2}{*}{ Dependent variable } & \multicolumn{5}{|c|}{ Attend private tutoring $=1$; Not attend private coaching $=0$} & \multicolumn{5}{|c|}{$\begin{array}{l}\text { Log of private tutoring expenditure condition on attending } \\
\text { private coaching }\end{array}$} \\
\hline & Primary & Middle & Secondary & $\begin{array}{c}\text { Sr. } \\
\text { Secondary }\end{array}$ & Tertiary & Primary & Middle & Secondary & $\begin{array}{c}\text { Sr. } \\
\text { Secondary }\end{array}$ & Tertiary \\
\hline \multicolumn{11}{|l|}{ Reference: Government Schools } \\
\hline Private-unaided & $\begin{array}{c}0.016 * * * \\
(0.006)\end{array}$ & $\begin{array}{c}0.019^{* * *} \\
(0.010)\end{array}$ & $\begin{array}{c}0.033^{* * *} \\
(0.014)\end{array}$ & $\begin{array}{c}0.026 \\
(0.017)\end{array}$ & $\begin{array}{c}-0.034 * * \\
(0.015)\end{array}$ & $\begin{array}{c}0.026 \\
(0.037)\end{array}$ & $\begin{array}{c}0.009 \\
(0.044)\end{array}$ & $\begin{array}{c}0.008 \\
(0.047)\end{array}$ & $\begin{array}{l}-0.067 \\
(0.064)\end{array}$ & $\begin{array}{c}0.040 \\
(0.088)\end{array}$ \\
\hline Private-Aided & $\begin{array}{c}0.038 * * * \\
(0.007)\end{array}$ & $\begin{array}{c}0.050^{* * * *} \\
(0.009)\end{array}$ & $\begin{array}{c}0.035^{* * * *} \\
(0.012)\end{array}$ & $\begin{array}{c}0.045^{* * *} \\
(0.014)\end{array}$ & $\begin{array}{c}0.013 \\
(0.013)\end{array}$ & $\begin{array}{c}0.046 \\
(0.036)\end{array}$ & $\begin{array}{c}0.091 \text { ** } \\
(0.038)\end{array}$ & $\begin{array}{c}0.038 \\
(0.039)\end{array}$ & $\begin{array}{c}0.114 * * \\
(0.051)\end{array}$ & $\begin{array}{l}-0.035 \\
(0.072)\end{array}$ \\
\hline English Medium & $\begin{array}{c}0.041 * * * \\
(0.007)\end{array}$ & $\begin{array}{l}-0.012 \\
(0.011)\end{array}$ & $\begin{array}{c}0.023 \\
(0.015)\end{array}$ & $\begin{array}{c}0.080^{* * *} \\
(0.015)\end{array}$ & $\begin{array}{c}0.033^{* *} \\
(0.014)\end{array}$ & $\begin{array}{c}0.147^{* * * *} \\
(0.033)\end{array}$ & $\begin{array}{c}0.243^{* * *} \\
(0.043)\end{array}$ & $\begin{array}{c}0.227^{* * *} \\
(0.046)\end{array}$ & $\begin{array}{c}0.326^{* * * *} \\
(0.053)\end{array}$ & $\begin{array}{l}-0.004 \\
(0.070)\end{array}$ \\
\hline Rural & $\begin{array}{c}-0.080^{* * * *} \\
(0.004)\end{array}$ & $\begin{array}{c}-0.099 * * * \\
(0.007)\end{array}$ & $\begin{array}{c}-0.122 * * * \\
(0.010)\end{array}$ & $\begin{array}{c}-0.089 * * * \\
(0.014)\end{array}$ & $\begin{array}{l}-0.026^{*} \\
(0.013)\end{array}$ & $\begin{array}{c}-0.293 * * * \\
(0.023)\end{array}$ & $\begin{array}{c}-0.269 * * * \\
(0.028)\end{array}$ & $\begin{array}{c}-0.294 * * * \\
(0.033)\end{array}$ & $\begin{array}{c}-0.197 * * * \\
(0.049)\end{array}$ & $\begin{array}{c}-0.135^{*} \\
(0.069)\end{array}$ \\
\hline \multicolumn{11}{|l|}{ Reference: Non-SC/ST } \\
\hline Scheduled Castes & $\begin{array}{c}-0.021 * * * \\
(0.004)\end{array}$ & $\begin{array}{c}-0.024 * * * \\
(0.006)\end{array}$ & $\begin{array}{c}-0.041 * * * \\
(0.010)\end{array}$ & $\begin{array}{l}-0.002 \\
(0.014)\end{array}$ & $\begin{array}{c}0.012 \\
(0.015)\end{array}$ & $\begin{array}{c}-0.110 * * * \\
(0.022)\end{array}$ & $\begin{array}{c}-0.113 * * * \\
(0.027)\end{array}$ & $\begin{array}{c}-0.100 * * * \\
(0.033)\end{array}$ & $\begin{array}{l}-0.051 \\
(0.053)\end{array}$ & $\begin{array}{l}-0.079 \\
(0.077)\end{array}$ \\
\hline Scheduled Tribes & $\begin{array}{c}-0.050^{* * * *} \\
(0.006)\end{array}$ & $\begin{array}{c}-0.059^{* * *} \\
(0.010)\end{array}$ & $\begin{array}{c}-0.099 * * * \\
(0.017)\end{array}$ & $\begin{array}{l}-0.046^{*} \\
(0.025)\end{array}$ & $\begin{array}{c}0.027 \\
(0.031)\end{array}$ & $\begin{array}{c}-0.096^{* *} \\
(0.043)\end{array}$ & $\begin{array}{c}-0.111^{* *} \\
(0.056)\end{array}$ & $\begin{array}{l}-0.100 \\
(0.070)\end{array}$ & $\begin{array}{l}-0.022 \\
(0.114)\end{array}$ & $\begin{array}{c}0.195 \\
(0.170)\end{array}$ \\
\hline \multicolumn{11}{|l|}{ Reference: Head-below primary } \\
\hline Head-primary educated & $\begin{array}{c}0.013 * * * \\
(0.004)\end{array}$ & $\begin{array}{c}0.016^{* *} \\
(0.007)\end{array}$ & $\begin{array}{c}0.007 \\
(0.011)\end{array}$ & $\begin{array}{c}0.008 \\
(0.016)\end{array}$ & $\begin{array}{c}0.009 \\
(0.019)\end{array}$ & $\begin{array}{c}0.082 * * * \\
(0.023)\end{array}$ & $\begin{array}{c}0.020 \\
(0.030)\end{array}$ & $\begin{array}{c}0.008 \\
(0.038)\end{array}$ & $\begin{array}{c}0.035 \\
(0.063)\end{array}$ & $\begin{array}{l}0.184 * \\
(0.103)\end{array}$ \\
\hline Head-middle educated & $\begin{array}{c}0.022 * * * \\
(0.004)\end{array}$ & $\begin{array}{c}0.038^{* * * *} \\
(0.007)\end{array}$ & $\begin{array}{c}0.015 \\
(0.010)\end{array}$ & $\begin{array}{c}0.036 \text { ** } \\
(0.015)\end{array}$ & $\begin{array}{c}0.027 \\
(0.017)\end{array}$ & $\begin{array}{c}0.115 * * * \\
(0.024)\end{array}$ & $\begin{array}{c}0.151^{* * * *} \\
(0.030)\end{array}$ & $\begin{array}{c}0.024 \\
(0.035)\end{array}$ & $\begin{array}{c}0.093 \\
(0.059)\end{array}$ & $\begin{array}{c}0.116 \\
(0.090)\end{array}$ \\
\hline Head-secondary educated & $\begin{array}{c}0.037 * * * \\
(0.005)\end{array}$ & $\begin{array}{c}0.043^{* * *} \\
(0.008)\end{array}$ & $\begin{array}{c}0.044 * * * \\
(0.012)\end{array}$ & $\begin{array}{c}0.048^{* * *} \\
(0.016)\end{array}$ & $\begin{array}{c}0.021 \\
(0.017)\end{array}$ & $\begin{array}{c}0.147 * * * \\
(0.029)\end{array}$ & $\begin{array}{c}0.201^{* * *} \\
(0.036)\end{array}$ & $\begin{array}{c}0.083^{* *} \\
(0.040)\end{array}$ & $\begin{array}{c}0.171 * * * \\
(0.060)\end{array}$ & $\begin{array}{c}0.255^{\text {*** }} \\
(0.093)\end{array}$ \\
\hline Head-Sr. Secondary educated & $\begin{array}{c}0.018 * * * \\
(0.007)\end{array}$ & $\begin{array}{c}0.059^{* * * *} \\
(0.010)\end{array}$ & $\begin{array}{c}0.107^{* * * *} \\
(0.015)\end{array}$ & $\begin{array}{c}0.044^{* * *} \\
(0.019)\end{array}$ & $\begin{array}{l}-0.011 \\
(0.018)\end{array}$ & $\begin{array}{c}0.221 * * * \\
(0.038)\end{array}$ & $\begin{array}{c}0.283^{* * * *} \\
(0.044)\end{array}$ & $\begin{array}{c}0.243^{* * * *} \\
(0.047)\end{array}$ & $\begin{array}{c}0.238^{* * * *} \\
(0.070)\end{array}$ & $\begin{array}{r}0.374 * * * \\
(0.095)\end{array}$ \\
\hline Head-tertiary educated & $\begin{array}{l}-0.001 \\
(0.007)\end{array}$ & $\begin{array}{c}0.035^{* * * *} \\
(0.011)\end{array}$ & $\begin{array}{c}0.034 * * \\
(0.016)\end{array}$ & $\begin{array}{c}0.129^{* * * *} \\
(0.019)\end{array}$ & $\begin{array}{c}0.003 \\
(0.018)\end{array}$ & $\begin{array}{c}0.351^{* * * *} \\
(0.037)\end{array}$ & $\begin{array}{c}0.329^{* * * *} \\
(0.046)\end{array}$ & $\begin{array}{c}0.240^{* * * *} \\
(0.051)\end{array}$ & $\begin{array}{c}0.247 * * * \\
(0.067)\end{array}$ & $\begin{array}{c}0.465^{\text {***** }} \\
(0.096)\end{array}$ \\
\hline Head is Female & $\begin{array}{l}-0.008 \\
(0.005)\end{array}$ & $\begin{array}{c}0.007 \\
(0.008)\end{array}$ & $\begin{array}{l}0.024 * \\
(0.012)\end{array}$ & $\begin{array}{c}0.026 \\
(0.017)\end{array}$ & $\begin{array}{l}-0.015 \\
(0.016)\end{array}$ & $\begin{array}{c}0.041 \\
(0.031)\end{array}$ & $\begin{array}{l}-0.049 \\
(0.038)\end{array}$ & $\begin{array}{c}0.005 \\
(0.042)\end{array}$ & $\begin{array}{c}0.086 \\
(0.064)\end{array}$ & $\begin{array}{l}-0.025 \\
(0.091)\end{array}$ \\
\hline Female & $\begin{array}{c}-0.010^{* * * *} \\
(0.003)\end{array}$ & $\begin{array}{c}-0.022^{* * * *} \\
(0.005)\end{array}$ & $\begin{array}{c}-0.040 * * * \\
(0.007)\end{array}$ & $\begin{array}{c}-0.033 * * * \\
(0.010)\end{array}$ & $\begin{array}{l}-0.007 \\
(0.010)\end{array}$ & $\begin{array}{l}-0.015 \\
(0.016)\end{array}$ & $\begin{array}{l}-0.004 \\
(0.020)\end{array}$ & $\begin{array}{l}-0.040^{*} \\
(0.024)\end{array}$ & $\begin{array}{c}-0.082 * * \\
(0.037)\end{array}$ & $\begin{array}{l}-0.005 \\
(0.048)\end{array}$ \\
\hline Age (Years) & $\begin{array}{c}0.007 * * * \\
(0.001)\end{array}$ & $\begin{array}{l}-0.002 \\
(0.002)\end{array}$ & $\begin{array}{c}0.003 \\
(0.003)\end{array}$ & $\begin{array}{c}-0.015 * * * \\
(0.004)\end{array}$ & $\begin{array}{c}-0.014 * * * \\
(0.003)\end{array}$ & $\begin{array}{c}0.050^{* * * *} \\
(0.004)\end{array}$ & $\begin{array}{c}0.037^{* * * *} \\
(0.007)\end{array}$ & $\begin{array}{c}0.038^{* * * *} \\
(0.009)\end{array}$ & $\begin{array}{l}-0.025^{*} \\
(0.014)\end{array}$ & $\begin{array}{l}-0.009 \\
(0.014)\end{array}$ \\
\hline
\end{tabular}




\section{Reference: Number of sibling is zero}

Number of sibling in age 6-24 is one

\begin{tabular}{|c|c|c|c|c|c|c|c|c|c|}
\hline $0.007 *$ & $0.018 * *$ & 0.009 & 0.012 & $0.025^{*}$ & 0.001 & -0.023 & $-0.069 *$ & 0.014 & $0.117^{*}$ \\
\hline (0.004) & (0.009) & $(0.013)$ & $(0.016)$ & $(0.013)$ & $(0.020)$ & $(0.031)$ & $(0.038)$ & $(0.052)$ & $(0.063)$ \\
\hline$-0.018 * * *$ & -0.007 & -0.006 & 0.010 & $0.032 * *$ & $-0.044^{*}$ & -0.039 & -0.013 & -0.075 & 0.120 \\
\hline$(0.005)$ & (0.009) & $(0.013)$ & $(0.016)$ & $(0.015)$ & $(0.024)$ & $(0.034)$ & $(0.041)$ & $(0.056)$ & $(0.075)$ \\
\hline$-0.033 * * *$ & $-0.036 * * *$ & -0.014 & -0.026 & 0.017 & $-0.080^{* *}$ & $-0.089 * *$ & -0.037 & -0.066 & $0.249 * *$ \\
\hline$(0.005)$ & $(0.010)$ & $(0.015)$ & $(0.020)$ & $(0.020)$ & $(0.033)$ & $(0.044)$ & $(0.050)$ & $(0.072)$ & $(0.107)$ \\
\hline$-0.033 * * *$ & $-0.022 * *$ & -0.017 & -0.016 & -0.000 & -0.046 & $-0.109 * *$ & 0.024 & 0.091 & 0.107 \\
\hline$(0.005)$ & $(0.011)$ & $(0.016)$ & $(0.022)$ & $(0.024)$ & $(0.036)$ & $(0.049)$ & $(0.056)$ & $(0.082)$ & $(0.165)$ \\
\hline $0.010 * * *$ & $0.011 * * *$ & -0.003 & -0.006 & $-0.008^{*}$ & $0.204 * * *$ & $0.089 * * *$ & $0.082 * * *$ & $0.098 * * *$ & $0.097 * * *$ \\
\hline$(0.003)$ & $(0.004)$ & $(0.006)$ & $(0.006)$ & $(0.005)$ & $(0.016)$ & $(0.018)$ & $(0.019)$ & $(0.023)$ & $(0.025)$ \\
\hline 0.002 & 0.003 & $0.018 *$ & -0.016 & 0.008 & 0.028 & $0.061 * *$ & $0.054 *$ & 0.005 & 0.154 \\
\hline$(0.005)$ & $(0.006)$ & $(0.010)$ & $(0.016)$ & $(0.021)$ & $(0.024)$ & $(0.026)$ & $(0.032)$ & $(0.053)$ & $(0.102)$ \\
\hline 0.008 & -0.001 & 0.014 & -0.020 & $0.033 *$ & $0.110 * * *$ & $0.047 *$ & $0.061 *$ & $0.104 * *$ & $0.348 * * *$ \\
\hline$(0.006)$ & $(0.006)$ & $(0.010)$ & $(0.015)$ & $(0.018)$ & $(0.029)$ & $(0.027)$ & $(0.032)$ & (0.049) & $(0.087)$ \\
\hline 0.012 & $-0.021 * *$ & $0.024 * *$ & $-0.038 * *$ & -0.024 & $0.199 * * *$ & $0.108 * *$ & $0.155^{* * *}$ & $0.136 * * *$ & $0.335^{* * *}$ \\
\hline$(0.010)$ & $(0.010)$ & $(0.012)$ & $(0.015)$ & $(0.017)$ & $(0.045)$ & $(0.047)$ & $(0.040)$ & $(0.052)$ & $(0.083)$ \\
\hline $0.020 * * *$ & $0.031 * * *$ & $0.044 * * *$ & 0.024 & 0.005 & & & & & \\
\hline$(0.004)$ & $(0.007)$ & $(0.013)$ & $(0.021)$ & $(0.025)$ & & & & & \\
\hline $0.034 * * *$ & $0.046^{* * *}$ & $0.069 * * *$ & $0.082 * * *$ & $0.046^{*}$ & & & & & \\
\hline$(0.005)$ & $(0.008)$ & $(0.014)$ & $(0.020)$ & $(0.025)$ & & & & & \\
\hline $0.045 * * *$ & $0.062 * * *$ & $0.089 * * *$ & $0.081 * * *$ & $0.054 * *$ & & & & & \\
\hline$(0.005)$ & $(0.008)$ & $(0.013)$ & $(0.020)$ & $(0.024)$ & & & & & \\
\hline \multirow{4}{*}{$\begin{array}{c}0.058 * * * \\
(0.006)\end{array}$} & $0.105 * * *$ & $0.132 * * *$ & $0.118^{* * *}$ & $0.093 * * *$ & & & & & \\
\hline & $(0.009)$ & $(0.015)$ & $(0.021)$ & $(0.024)$ & & & & & \\
\hline & & & & & $0.351 * * *$ & $0.395^{* * *}$ & $0.391 * * *$ & $0.447 * * *$ & $0.154 * * *$ \\
\hline & & & & & $(0.022)$ & $(0.028)$ & $(0.033)$ & $(0.045)$ & $(0.058)$ \\
\hline $0.063 * * *$ & $0.187 * * *$ & $0.278 * * *$ & $0.563 * * *$ & $0.452 * * *$ & $1.731 * * *$ & $2.372 * * *$ & $2.597 * * *$ & $3.137 * * *$ & $5.264 * * *$ \\
\hline$(0.018)$ & $(0.033)$ & $(0.057)$ & $(0.079)$ & $(0.069)$ & $(0.219)$ & $(0.289)$ & $(0.357)$ & $(0.502)$ & $(0.640)$ \\
\hline 44,318 & 21,019 & 12,067 & 7,205 & 5,954 & 6,838 & 4,737 & 4,056 & 2,373 & 1,203 \\
\hline 0.313 & 0.382 & 0.366 & 0.362 & 0.316 & 0.570 & 0.572 & 0.559 & 0.597 & 0.605 \\
\hline
\end{tabular}

Note: All the models include district fixed effects. 